\title{
COMPARATIVE STUDY OF TWO PURIFIED INULINASES FROM THERMOPHILE THIELAVIA TERRESTRIS NRRL 8126 AND MESOPHILE ASPERGILLUS FOETIDUS NRRL 337 GROWN ON CICHORIUM INTYBUS L.
}

\section{Eman Mohamed Fawzi}

Biological and Geological Sciences Department, Faculty of Education, Ain Shams University, Roxy, Heliopolis, P.C.11757,

$$
\text { Cairo, Egypt. }
$$

\begin{abstract}
Thirty fungal species grown on Cichorium intybus L. root extract as a sole carbon source, were screened for the production of exo-inulinase activities. The thermophile Thielavia terrestris NRRL 8126 and mesophile Aspergillus foetidus NRRL 337 gave the highest production levels of inulinases I \& II at 50 and $24{ }^{\circ} \mathrm{C}$ respectively. Yeast extract and peptone were the best nitrogen sources for highest production of inulinases I \& II at five and seven days of incubation respectively. The two inulinases I \& II were purified to homogeneity by gel-filtration and ion-exchange chromatography with 66.0 and 42.0 fold of purification respectively. The optimum temperatures of purified inulinases I \& II were 75 and $50{ }^{\circ} \mathrm{C}$ respectively. Inulinase I was more thermostable than the other one. The optimum $\mathrm{pH}$ for activity was found to be 4.5 and 5.5 for inulinases I \& II respectively. A comparatively lower Michaelis-Menten constant ( $2.15 \mathrm{mg} / \mathrm{ml})$ and higher maximum initial velocity $(115 \mu \mathrm{mol} / \mathrm{min} / \mathrm{mg}$ of protein) for inulinase I on inulin demonstrated the exoinulinase's greater affinity for inulin substrate. These findings are significant for its potential industrial application. The molecular mass of the inulinases I \& II were estimated to be $72 \& 78 \mathrm{kDa}$ respectively by sodium dodecyl sulfate-polyacrylamide gel electrophoresis.
\end{abstract}

Key words: Inulinases, Production, Purification, Thermophile, Thermostability.

\section{INTRODUCTION}

Inulin is a potential source of fructose, or fruit sugar (22). It is present as a reserve carbohydrate in the roots and tubers of composite plants such as Jerusalem artichoke (Helianthus tuberosus L.), Chicory (Cichorium intybus L.), Sunflower (Helianthus annuus L.) and Dahlia (Dahlia pinnata Cav.). Chemically, it is a polymer $(\mathrm{MM}=60000)$ of fructose units linked by $\beta-2,1$ bonds with a terminal glucose residue linked by $\alpha-1,2$ bonds. This polymer is a potential feedstock for fuel ethanol production and fructose products. These fructooligosaccharides are widely used in many countries as food ingredients since they show many health benefits without any known harmful risks such as toxicity, carcinogenicity and mortality $(3,13,24,35)$. Moreover, crude inulin from chicory root extracts is hydrolyzed faster than pure inulin $(36,37)$.

\footnotetext{
*Corresponding Author. Mailing address: Biological and Geological Sciences Department, Faculty of Education, Ain Shams University, Roxy, Heliopolis,
} P.C.11757, Cairo, Egypt.; Tel: +20 10 5217166.; E-mail: emanfawzy@ hotmail.com 
Chicory in its processed form serves as a coffee substitute in the manufacture of various coffee blends.

Inulin hydrolyzing enzymes (inulinases) are produced by plants, filamentous fungi, yeasts, and bacteria. Among the filamentous fungi, Aspergillus and Penicillium species are common inulinase producers $(5,9,21,25,42,43)$. Inulinases are classified as endo - or exoinulinases, depending on their mode of action. Endoinulinases (2,1- $\beta$-D-fructan fructanohydrolase; EC 3.2.1.7) are specific for inulin and hydrolyse it by breaking the bonds between fructose units that are located away from the ends of the polymer chain, to produce oligosaccharides. Exo-inulinases ( $\beta$-Dfructohydrolase; EC 3.2.1.80), split terminal fructose units in sucrose, raffinose and inulin to liberate fructose $(14,28,32)$. Unfortunately, only a few of inulinases required for industrial applications have an optimum temperature of $50{ }^{\circ} \mathrm{C}$ or higher $(14,16,19,41)$. Therefore the search for inulinase fungal producers and the purification of these enzymes have received increasing attention. The purification and properties of inulinases have been studied in many fungal species $(5,7,15$, $18,29,30)$.

Thermophilic fungi can produce inulinases of higher optimum temperature which is an extremely important factor in the commercial industrial production of fructose or fructooligosaccharides from inulin. This is mainly because high temperatures ensure proper solubility of inulin and also prevent microbial contamination $(9,14,46,47)$. Moreover, higher thermostability of the industrially important enzymes also brings down the cost of production because lower amounts of enzyme are required to produce the desired product (16).

This work aims at the comparison between the optimum conditions for the production, purification and characterization of extracellular inulinases from the thermophile Thielavia terrestris NRRL 8126 and the mesophile Aspergillus foetidus NRRL 337. The aforementioned fungi were chosen after performing an initial screening of 30 fungal species belonging to 11 genera for their capability to produce inulinases when grown on Cichorium intybus root extract.

\section{MATERIALS AND METHODS}

\section{Microorganisms and maintenance}

All the micro-organisms used throughout this work were obtained from NRRL (Agricultural Research Service Culture Collection). They were kindly provided by United States Department of Agriculture (USDA), New Orleans, Louisiana 70179. The studied fungi were maintained in agar slants and in Petri dishes at $4{ }^{\circ} \mathrm{C}$ in their respective maintenance media which were described by DSMZ Catalogue (8) in Table 1, i.e. maintenance medium no.129 (Potato Dextrose Agar), 90 (Malt extract Peptone Agar), 190 (YpSs-Yeast protein Soluble starch), 189 (Oat Flake) and 310 (V-8 vegetable juice agar).

\section{Preparation of Cichorium intybus root extract}

Chicory was gathered from Sharkeya governorate north east of Egypt and washed with cold water, grounded and blended by a mixer as a known weight of fresh roots $(2 \%)$ with of $0.2 \mathrm{M}$ citrate phosphate buffer ( $\mathrm{pH}$ 6.0). The whole blend of Chicory extract was used as a sole carbon source throughout the study.

\section{Inoculum preparation}

Spores from the agar slants were suspended in sterile saline solution $(0.85 \% \mathrm{NaCl})$ containing $0.01 \%$ Tween 80 to obtain $2.0 \times 10^{6}$ spore $\mathrm{ml}^{-1}$. For all the experiments, $1 \mathrm{ml}$ of this suspension was used.

\section{Screening of fungal species for their potentiality to produce exo-inulinase}

Fungal species were incubated for 6 days in $250 \mathrm{ml}$ capacity Erlenmeyer conical flasks (triplicate) containing $50 \mathrm{ml}$ of basal medium for the production of inulinases (2\% chicory root extract, $0.05 \% \mathrm{MgSO}_{4} 7 \mathrm{H}_{2} 0,0.2 \% \mathrm{NH}_{4} \mathrm{H}_{2} \mathrm{PO}_{4}$ and $0.1 \%$ $\left.\mathrm{KH}_{2} \mathrm{PO}_{4}\right)$. The $\mathrm{pH}$ was adjusted at $6.0(27,51)$. The incubation was done at the ideal temperature for each fungus as previously 
mentioned in Table 1. At the end of the fermentation process, the contents of each flask were gathered, and rapidly filtered using Whatman No:1 filter paper. The filtrate was then subjected to an enzyme assay for the determination of inulinases activity, in order to select the best fungi that were chosen for further studies.

\section{Inulinase assay}

One $\mathrm{ml}$ of Crude enzyme was added to $1 \mathrm{ml}$ of $0.5 \%(\mathrm{w} / \mathrm{v})$ inulin (Sigma) in 0.2 M citrate phosphate buffer ( $\mathrm{pH}$ 6.0) and incubated at $40{ }^{\circ} \mathrm{C}$ for $20 \mathrm{~min}$. The reaction was terminated by boiling for $5 \mathrm{~min}$ (19). The reducing sugars were subsequently analysed by 3.5 dinitrosalicylic-DNSA reagent (23). One unit of inulinase (U) was defined as the amount of enzyme, which produced $1 \mu \mathrm{mol} \mathrm{min}^{-1}$ of fructose under the assay conditions as described above.

\section{Protein determination}

Total protein was determined by using bovine serum albumin as protein standard (4). All the assay were carried out in triplicates.

\section{Effect of different concentration of Chicory root extract on inulinases production.}

Mixtures of basal medium $\left(0.05 \% \mathrm{MgSO}_{4} 7 \mathrm{H}_{2} 0,0.2 \%\right.$ $\mathrm{NH}_{4} \mathrm{H}_{2} \mathrm{PO}_{4}$ and $0.1 \% \quad \mathrm{KH}_{2} \mathrm{PO}_{4}$ ) with Chicory root extract of different concentrations $(2.0,3.0,4.0,5.0 \%)$ were prepared. The $\mathrm{pH}$ was adjusted at 6.0, inoculated with spore suspension of the selected fungi and incubated as described before, then the inulinases activities were determined.

\section{Effect of different nitrogen sources on inulinases production}

Equimolecular amounts of four organic nitrogen source (asparagines, casein, peptone, yeast extract) and five inorganic nitrogen sources $\left(\mathrm{NaNO}_{3},\left(\mathrm{NH}_{4}\right)_{2} \mathrm{HPO}_{4}, \mathrm{NH}_{4} \mathrm{SO}_{4}, \mathrm{NH}_{4} \mathrm{NO}_{3}\right.$, $\mathrm{NH}_{4} \mathrm{Cl}$ ) were replaced by the original nitrogen sources in the cultivation media of the selected fungi.

\section{Effect of different incubation periods on inulinases production}

Triplicate flasks were inoculated with each of the experimental fungi using the best concentration of Chicory root extract and the best nitrogen source from the previous experiments and incubated for different periods (3-8 days).

\section{Enzyme purification and characterization}

Aliquots of cell-free dialysate (CFD) were separately treated with $\left(\mathrm{NH}_{4}\right)_{2} \mathrm{SO}_{4}$ using range of saturation from 0.5 to 0.9; methanol or iso-propanol in a ratio of $1: 1,2: 1,3: 1,4: 1$ or 5:1 (alcohol : CFD). All samples were left overnight at 4 ${ }^{\circ} \mathrm{C}$. The precipitates were collected by centrifugation at $12 \mathrm{x}$ $10^{3} \mathrm{~g}$ for $15 \mathrm{~min}$., dissolved in $5 \mathrm{ml}$ acetate buffer $(0.2 \mathrm{M}$, pH 6.0) and dialyzed overnight against the same buffer. Protein precipitates containing most of the enzyme activity were then fractionated on Sephadex G-100 column $(2.5 \times 82 \mathrm{~cm})$ of Fraction Collector (Fra100, Pharmacia-Fin Chemicals) preequilibrated with acetate buffer. The column was eluted with the same buffer at $20 \mathrm{ml} \mathrm{h}^{-1}$. Active fractions $(5 \mathrm{ml}$ each) were pooled, lyophilized and subjected for further purification on DEAE-cellulose column (Diethylaminoethylcellulose, fast flow, fibrous form-Sigma product) pretreated with distilled water followed by washing with $1 \mathrm{~N} \mathrm{HCl}$ and water till the $\mathrm{pH}$ of the suspension was about $6.0(31,34)$. It was then washed several times with $0.5 \mathrm{~N} \mathrm{NaOH}$ until no more colour was removed. Column was eluted with gradient of $0-0.8 \mathrm{M} \mathrm{NaCl}$ prepared in $0.2 \mathrm{M}$ acetate buffer ( $\mathrm{pH}$ 6.0) at a flow rate of $10 \mathrm{ml} \mathrm{h}^{-1}$ and $5 \mathrm{ml}$ fractions were collected and dialyzed once again to remove $\mathrm{Na}^{+}$and $\mathrm{Cl}^{-}$. This enzyme was lyophilized and stored at $0{ }^{\circ} \mathrm{C}$ for further investigations.

\section{Characterization of the purified inulinases}

Effect of temperature and thermal stability: The two purified inulinases were incubated with inulin at various temperatures ranging from 30 to $80{ }^{\circ} \mathrm{C}$. Enzymes activity were measured as previously described. However, for determination 
of thermal stability, the enzymes were incubated for variable durations (0 to $60 \mathrm{~min}$ ) at fixed temperatures. The residual activity was estimated under standard assay conditions after incubation intervals and expressed as relative activity (\%).

Effect of pH and pH stability: The optimum $\mathrm{pH}$ for the enzyme activity was determined by carrying out the reaction at different $\mathrm{pH}$ values using different buffers $(0.1 \mathrm{M}$ phosphate, $\mathrm{pH}$ 3.5-7.0; 0.2 M Tris-HCl, $\mathrm{pH}$ 7.0-9.0). To determine $\mathrm{pH}$ stability, the enzyme was incubated in the presence of $\mathrm{pH}$ values within the above cited for $60 \mathrm{~min}$ at room temperature $\left(20{ }^{\circ} \mathrm{C}\right)$. The original $\mathrm{pH}$ value was then restored and the residual activity was estimated under standard assay conditions. The results were expressed as relative activity (\%) referred to the activity observed before incubation.

Effect of substrate concentration: Inulinases were incubated with different concentrations of inulin $(1-9 \mathrm{mg} / \mathrm{ml})$ at $40{ }^{\circ} \mathrm{C}$ for $20 \mathrm{~min}$. The reaction was stopped and the enzyme activity was measured under the standard assay conditions as previously described. The kinetic parameters (MichaelisMenten constant, $\mathrm{K}_{\mathrm{m}}$ and maximal reaction velocity, $\mathrm{Vmax}$ ) were estimated.

Molecular mass determination: The molecular mass of the purified inulinases was estimated in sodium dodecyl sulphate-polyacrylamide gel (SDS-PAGE) using standard protein markers (myosin, $205 \mathrm{kDa}$; B-galactosidase, $116 \mathrm{kDa}$; phosphorylase b, $97 \mathrm{kDa}$; bovine serum albumin, $67 \mathrm{kDa}$; egg albumin, $45 \mathrm{kDa}$; glyceraldehyde-3-phosphate, 36; carbonic anhydrase, 29 kDa; Sigma) (20).

Statistical validation of treatment effects: The mean, standard deviation, T-score and probability "P" values of 3 replicates of the investigated factors and the control were computed according to the mathematical principles described by Glantz (17). Results were considered highly significant, significant or non-significant where $\mathrm{P}<0.01,>0.01$ and $<$ $0.05,>0.05$ respectively. The comparison of all means was also carried out by Anova test for analysis of variance between groups (52).

\section{RESULTS}

Data are expressed in Table 1 as enzyme units produced in the culture medium filtrate of 30 fungal species belonging to 11 genera when grown on Cichorium intybus root extract under the conditions described in materials and methods. Throughout the text, the produced inulinases from the thermophile Thielavia terrestris NRRL 8126 and the mesophile Aspergillus foetidus NRRL 337 were given the numbers I \& II respectively. The aforementioned fungi showed relatively good production of inulinases I \& II (8.42 and $\left.8.36 \mathrm{U} \mathrm{ml}^{-1}\right)$ after 6 days incubation at 50 and $24^{\circ} \mathrm{C}$ respectively (Table 1).

The results in Table 2 showed that the best concentration of Chicory root extract in media was $4 \%$ for the two inulinases. This result was statistically analyzed and confirmed by

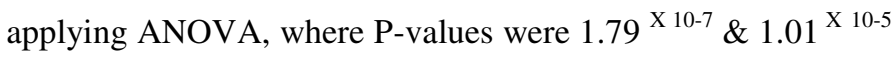
for inulinases I \& II respectively which reflect the high significance of these results. The concentration (4\%) was used as a control for the subsequent experiments.

When the effect of organic and inorganic nitrogen sources on inulinases production from the two selected fungi were investigated, it was observed that the yeast extract and peptone were the best organic sources which enhanced the production activity of inulinase I to 17.87 and inulinase II to $15.33 \mathrm{U} \mathrm{ml}^{-1}$ from $T$. terrestris and A. foetidus respectively (Table 3 ). The results in Table (4) showed that five and seven days of incubation were the best for inulinases I \& II production respectively.

The first step of purification of the two enzymes is carried out by precipitation of protein from the cell-free dialysate. Isopropanol (1:1) and methanol (1:1) were found to be superior in obtaining protein fraction having the highest total activity of 
inulinases I \& II respectively. This resulted in 2.8 folds of purification in case of inulinase I (Table 5) and 2.7 folds in case of inulinase II (Table 6) with yields of $86.4 \%$ and $94.9 \%$ of the original activities respectively.

Table 1. Screening of fungal species for their potentiality to produce exo-inulinase in the culture medium filtrate after 6 days of incubation.

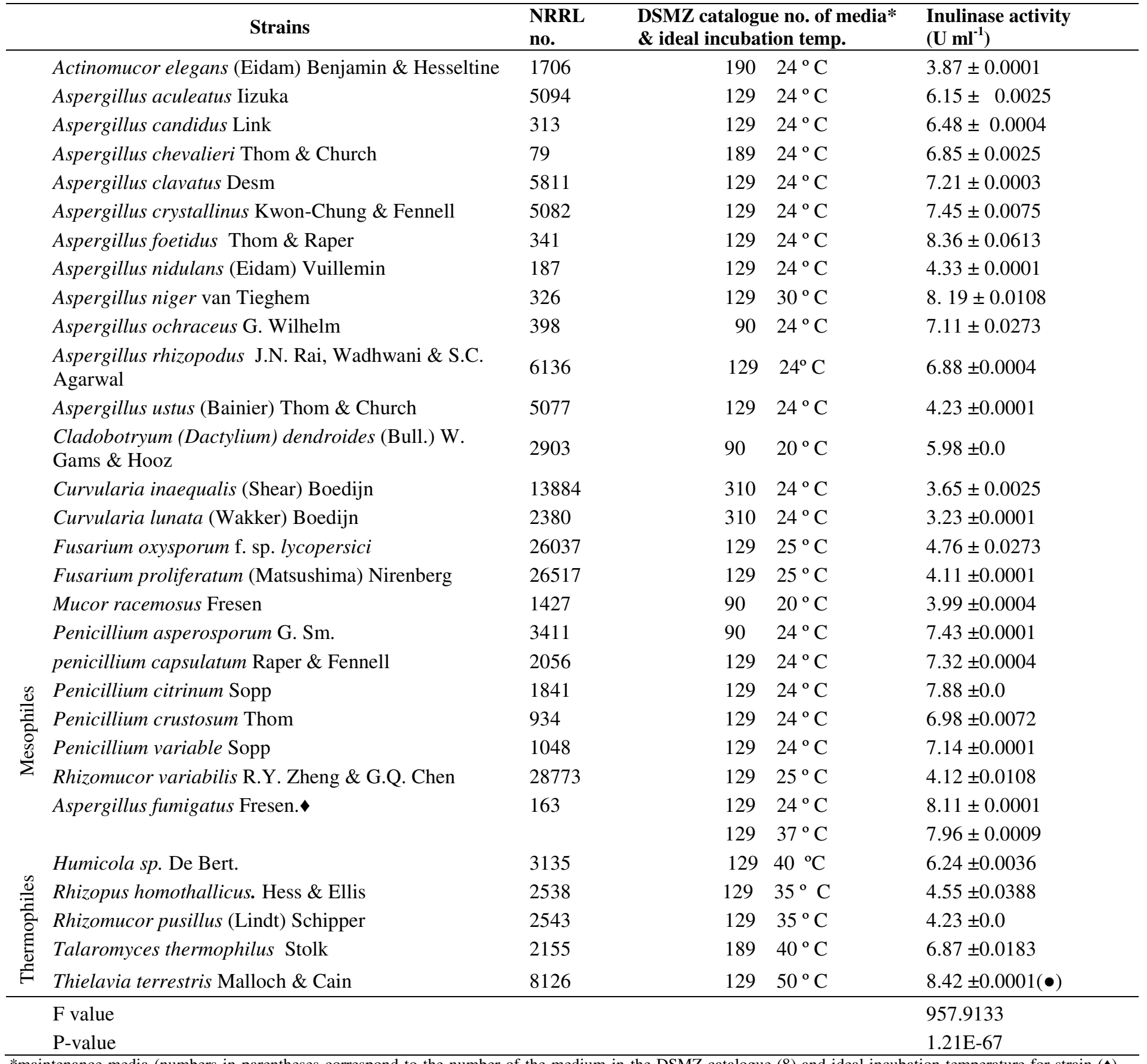

*maintenance media (numbers in parentheses correspond to the number of the medium in the DSMZ catalogue (8) and ideal incubation temperature for strain $(\diamond)$ thermotolerent fungus. The obtained data was statistically analyzed using ANOVA (Analysis of variance between groups) the greater $\mathrm{F}$ value and $\mathrm{P}<0.01$ reflect a highly significant relations between results; $(\bullet)=$ Highest value to which other data was statistically compared using T-Test. 
Table 2. Effect of different concentration of Chicory roots extract on the Production of inulinases by Thielavia terrestris and Aspergillus foetidus.

\begin{tabular}{ccc}
\hline $\begin{array}{c}\text { Concentration } \\
(\boldsymbol{\%})\end{array}$ & Inulinase I $^{\circ}$ & Inulinase II $^{\bullet}$ \\
2.0 & $8.42 \pm 0.0006$ & $8.36 \pm 0.0006$ \\
\cline { 2 - 3 } & $10.03 \pm 0.0027$ & $9.95 \pm 0.0052$ \\
4.0 & $11.67 \pm 0.0009(\bullet)$ & $12.32 \pm 0.0532(\bullet)$ \\
5.0 & $11.62 \pm 0.0112$ & $12.30 \pm 0.0675$ \\
\hline F value & 529.0743 & 135.6306 \\
P-value & $1.7924 \mathrm{E}-07$ & $1.0134 \mathrm{E}-05$ \\
\hline
\end{tabular}

${ }^{\circ}$ inulinase I from Thielavia terrestris

- inulinase II from Aspergillus foetidus

Table 3. The effect of different inorganic and organic nitrogen sources on inulinases production from Thielavia terrestris and Aspergillus foetidus

\begin{tabular}{|c|c|c|}
\hline \multirow[t]{2}{*}{ N sources } & \multicolumn{2}{|c|}{ Inulinases activity $\mathrm{U} \mathrm{ml}^{-1}$} \\
\hline & Inulinase I & Inulinase II \\
\hline Control & $11.67 \pm 0.0005(\bullet)$ & $12.32 \pm 0.0006(\bullet)$ \\
\hline Asparagines & $14.11 \pm 0.0273$ & $12.77 \pm 0.0004$ \\
\hline Casein & $15.76 \pm 0.0001$ & $14.01 \pm 0.0$ \\
\hline Peptone & $15.97 \pm 0.0112$ & $15.33 \pm 0.0432$ \\
\hline Yeast extract & $17.87 \pm 0.0016$ & $14.12 \pm 0.0031$ \\
\hline$\left(\mathrm{NH}_{4}\right)_{2} \mathrm{HPO}_{4}$ & $12.56 \pm 0.0036$ & $12.98 \pm 0.0004$ \\
\hline $\mathrm{NaNO}_{3}$ & $13.11 \pm 0.0076$ & $13.11 \pm 0.0273$ \\
\hline $\mathrm{NH}_{4} \mathrm{Cl}$ & $12.58 \pm 0.0244$ & $12.54 \pm 0.0004$ \\
\hline $\mathrm{NH}_{4} \mathrm{NO}_{3}$ & $12.05 \pm 0.0025$ & $12.39 \pm 0.0031$ \\
\hline $\mathrm{NH}_{4} \mathrm{SO}_{4}$ & $11.98 \pm 0.0016$ & $12.56 \pm 0.0508$ \\
\hline F value & 1445.3808 & 201.5735 \\
\hline $\mathrm{P}$-value & $1.1596 \mathrm{E}-23$ & $5.1972 \mathrm{E}-16$ \\
\hline
\end{tabular}

Table 4. The effect of different incubation periods on inulinases production from Thielavia terrestris and Aspergillus foetidus

\begin{tabular}{|c|c|c|}
\hline \multirow[t]{2}{*}{ Days } & \multicolumn{2}{|c|}{ Inulinases activity $\mathrm{U} \mathrm{ml}^{-1}$} \\
\hline & Inulinase I & Inulinase II \\
\hline 3 & $4.34 \pm 0.0002$ & $3.81 \pm 0.008$ \\
\hline 4 & $10.71 \pm 0.0004$ & $8.66 \pm 0.0013$ \\
\hline 5 & $18.11 \pm 0.0049(\bullet)$ & $13.67 \pm 0.0067$ \\
\hline 6 & $17.95 \pm 0.0001$ & $14.33 \pm 0.0657$ \\
\hline 7 & $17.22 \pm 0.1092$ & $15.67 \pm 0.0056(\bullet)$ \\
\hline 8 & $17.10 \pm 0.0075$ & $15.23 \pm 0.0247$ \\
\hline F value & 1154.2975 & 603.3838 \\
\hline P-value & $1.1668 \mathrm{E}-15$ & $5.6412 \mathrm{E}-14$ \\
\hline
\end{tabular}


Table 5. Precipitation of inulinase I from Thielavia terrestris cell-free dialysate by ammonium sulfate and low molecular weight alcohol

\begin{tabular}{|c|c|c|c|c|c|c|c|}
\hline \multicolumn{3}{|c|}{ Treatment } & $\begin{array}{c}\text { Total protein } \\
\text { (mg) }\end{array}$ & $\begin{array}{c}\text { Total activity } \\
\text { (U) }\end{array}$ & $\begin{array}{l}\text { Specific activity } \\
\text { (U/mg-1 protein) }\end{array}$ & $\begin{array}{c}\text { Recovery } \\
\%\end{array}$ & $\begin{array}{l}\text { Purification } \\
\text { (folds) }\end{array}$ \\
\hline \multirow{2}{*}{\multicolumn{3}{|c|}{$\begin{array}{l}\text { Cell-Free Filtrate } \\
\text { Cell-Free Dialysate }\end{array}$}} & 112.6 & 435 & 3.86 & 100 & 1.0 \\
\hline & & & 112.0 & 411 & 3.67 & 94.5 & 0.95 \\
\hline \multirow{5}{*}{ 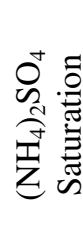 } & & 0.5 & 31.5 & 302 & 9.58 & 69.4 & 2.4 \\
\hline & & 0.6 & 33.1 & 311 & 9.39 & 71.4 & 2.4 \\
\hline & & 0.7 & 38.6 & 342 & 8.86 & 78.6 & 2.3 \\
\hline & & 0.8 & 45.3 & 319 & 7.04 & 73.3 & 1.8 \\
\hline & & 0.9 & 49.8 & 305 & 6.12 & 70.1 & 1.5 \\
\hline \multirow{10}{*}{  } & \multirow{5}{*}{$\begin{array}{l}\overline{0} \\
\vdots \\
0 \\
0 \\
0 \\
o \\
0 \\
0\end{array}$} & $1: 1$ & 34.3 & 376 & 10.96 & 86.4 & 2.8 \\
\hline & & $2: 1$ & 42.5 & 388 & 9.12 & 89.2 & 2.3 \\
\hline & & $3: 1$ & 46.0 & 401 & 8.71 & 92.2 & 2.3 \\
\hline & & $4: 1$ & 52.6 & 390 & 7.41 & 89.7 & 1.9 \\
\hline & & $5: 1$ & 65.3 & 376 & 5.75 & 86.5 & 1.5 \\
\hline & \multirow{5}{*}{ 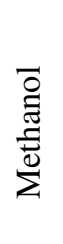 } & $1: 1$ & 30.0 & 290 & 9.66 & 66.6 & 2.5 \\
\hline & & $2: 1$ & 33.1 & 298 & 9.00 & 68.5 & 2.3 \\
\hline & & $3: 1$ & 35.6 & 307 & 8.62 & 70.5 & 2.2 \\
\hline & & $4: 1$ & 40.3 & 244 & 6.05 & 56.1 & 1.5 \\
\hline & & $5: 1$ & 43.5 & 227 & 5.21 & 52.2 & 1.3 \\
\hline
\end{tabular}

Table 6. Precipitation of inulinase II from Aspergillus foetidus cell-free dialysate by ammonium sulfate and low molecular weight alcohol

\begin{tabular}{|c|c|c|c|c|c|c|c|}
\hline \multicolumn{3}{|c|}{ Treatment } & $\begin{array}{l}\text { Total protein } \\
\text { (mg) }\end{array}$ & $\begin{array}{c}\text { Total activity } \\
\text { (U) }\end{array}$ & $\begin{array}{l}\text { Specific activity } \\
\text { (U/mg }{ }^{-1} \text { protein) }\end{array}$ & $\begin{array}{c}\text { Recovery } \\
\%\end{array}$ & $\begin{array}{l}\text { Purification } \\
\text { (folds) }\end{array}$ \\
\hline \multirow{2}{*}{\multicolumn{3}{|c|}{$\begin{array}{l}\text { Cell-Free Filtrate } \\
\text { Cell-Free Dialysate }\end{array}$}} & 129.3 & 314 & 2.4 & 100 & 1.0 \\
\hline & & & 129.0 & 305 & 2.3 & 97.1 & 0.98 \\
\hline \multirow{5}{*}{ 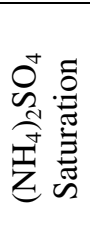 } & & 0.5 & 32.4 & 166 & 5.12 & 52.8 & 2.1 \\
\hline & & 0.6 & 35.2 & 174 & 4.94 & 55.4 & 2.0 \\
\hline & & 0.7 & 39.3 & 188 & 4.78 & 35.8 & 1.9 \\
\hline & & 0.8 & 43.7 & 181 & 4.14 & 57.6 & 1.7 \\
\hline & & 0.9 & 48.1 & 165 & 3.43 & 52.5 & 1.4 \\
\hline \multirow{10}{*}{ 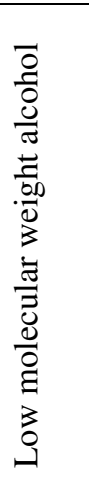 } & \multirow{5}{*}{  } & $1: 1$ & 39.1 & 215 & 5.49 & 68.4 & 2.2 \\
\hline & & $2: 1$ & 42.4 & 221 & 5.21 & 70.3 & 2.1 \\
\hline & & $3: 1$ & 45.8 & 232 & 5.06 & 73.8 & 2.1 \\
\hline & & $4: 1$ & 49.1 & 205 & 4.17 & 65.2 & 1.7 \\
\hline & & $5: 1$ & 51.4 & 201 & 3.91 & 64.0 & 1.6 \\
\hline & \multirow{5}{*}{ 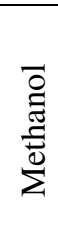 } & $1: 1$ & 45.6 & 298 & 6.53 & 94.9 & 2.7 \\
\hline & & $2: 1$ & 52.6 & 300 & 5.70 & 95.5 & 2.3 \\
\hline & & $3: 1$ & 56.6 & 266 & 4.69 & 84.7 & 1.9 \\
\hline & & $4: 1$ & 58.1 & 204 & 3.51 & 64.9 & 1.4 \\
\hline & & $5: 1$ & 63.2 & 179 & 2.83 & 57.0 & 1.1 \\
\hline
\end{tabular}


A summary of purification steps of inulinases I \& II was recorded in Tables 7 and 8 respectively. The precipitated enzymes were then purified by gel filtration through Sephadex G-100. In this step, inulinases I \& II were purified 15.1 and 13.7 fold with yields of about 69.2 and $77.1 \%$ and specific activities of 59.02 and $32.9 \mathrm{U} / \mathrm{mg}$ protein respectively (Tables $7 \& 8$ ). The activities were located in peak 2 for both inulinases I \& II (Figs.1 \& 3). The purification procedure was completed by anion exchange chromatography on DEAE-Cellulose using a linear sodium chloride gradient. The results showed that inulinase I was purified 66.0 fold obtaining a final specific activity of $254.9 \mathrm{U} / \mathrm{mg}$ protein (Table 7 ), the highest activity was detected in peak 3 (Fig. 2) Inulinase II was purified 42.0 fold to a specific activity of $100.9 \mathrm{U} / \mathrm{mg}$ protein (Table 8), the highest activity was detected in peak 2 (Fig. 4). Inulinases I \& II were separated at the concentration of $0.4 \mathrm{M}$ of $\mathrm{NaCl}$.

The optimum temperature of purified inulinase I was 75 ${ }^{\circ} \mathrm{C}$ and $50{ }^{\circ} \mathrm{C}$ for inulinase II (Fig. 5). Inulinase I retained its original activity after heating up to $75^{\circ} \mathrm{C}$ for $1 \mathrm{hr}$. and lost $35 \%$ of its activity at $90^{\circ} \mathrm{C}$ for $15 \mathrm{~min}$ (Fig. 6). However, inulinase II retained its original activity at $50^{\circ} \mathrm{C}$ only for $45 \mathrm{~min}$. and no activity was recorded after heating the enzyme (inulinase II) at $70{ }^{\circ} \mathrm{C}$ for $1 \mathrm{hr}$ (Fig. 7).

The optimum $\mathrm{pH}$ for activity was found to be 4.5 and 5.5 for inulinases I \& II (Figs. 8 \& 9) respectively. The pH stability exhibited by the inulinase I was between $4.5-5.0$, but at $5.5 \mathrm{pH}$ for inulinase II. The later enzyme retained only $94.4 \%$ of its original activity.

Effect of different inulin concentrations on the enzyme activity, as indicated by the initial rate of product formation, was studied. It was found that at low inulin concentrations, the enzymatic reaction was a first-order with respect to the substrate, but at higher concentrations it became zero-order and $\mathrm{V}_{\max }$ (maximum initial velocity) of the purified inulinases I \& II were recorded at 115 and $55 \mu \mathrm{mol} / \mathrm{min} / \mathrm{mg}$ of protein) respectively. From these data the apparent $\mathrm{K}_{\mathrm{m}}$ value of inulinases I \& II for inulin was calculated to be 2.15 and 3.45 $\mathrm{mg} / \mathrm{ml}$ respectively. The molecular mass of the inulinases I \& II were estimated to be $72 \& 78 \mathrm{kDa}$ respectively by using SDS-PAGE (Fig. 10).

Table 7. A Summary of treatments used for the purification of inulinase I From Thielavia terrestris grown on Chicory roots with yeast extract.

\begin{tabular}{|c|c|c|c|c|c|}
\hline Treatment & $\begin{array}{c}\text { Total protein } \\
(\mathbf{m g})\end{array}$ & $\begin{array}{c}\text { Total activity } \\
\text { (U) }\end{array}$ & $\begin{array}{l}\text { Specific activity } \\
\left(\mathrm{U} / \mathrm{mg}^{-1} \text { protein) }\right.\end{array}$ & $\begin{array}{c}\text { Recovery } \\
\% \\
\end{array}$ & $\begin{array}{c}\text { Purification } \\
\text { (folds) }\end{array}$ \\
\hline $\begin{array}{c}{ }^{*} \text { C.F.F. } \\
(\text { Volume }=200 \mathrm{ml})\end{array}$ & 112.6 & 435 & 3.86 & 100 & 1.0 \\
\hline$* *$ C.F.D. & 112.0 & 411 & 3.67 & 94.5 & 0.95 \\
\hline $\begin{array}{l}* * * \text { C.F.P. } \\
{[1: 1 \text { isopropanol] }}\end{array}$ & 34.3 & 376 & 10.96 & 86.4 & 2.8 \\
\hline Gel filtration (Sephadex G-100) & 5.1 & 301 & 59.02 & 69.2 & 15.1 \\
\hline $\begin{array}{l}\text { Ion-exchange chromatography } \\
\text { DEAE-Cellulose }\end{array}$ & 1.02 & 260 & 254.9 & 59.8 & 66.0 \\
\hline
\end{tabular}


Table 8. A Summary of treatments used for the purification of inulinase II From Aspergillus foetidus grown on Chicory roots with peptone.

\begin{tabular}{|c|c|c|c|c|c|}
\hline Treatment & $\begin{array}{c}\text { Total protein } \\
(\mathbf{m g})\end{array}$ & $\begin{array}{c}\text { Total activity } \\
\text { (U) }\end{array}$ & $\begin{array}{l}\text { Specific activity } \\
\text { (U/mg }{ }^{-1} \text { protein) }\end{array}$ & $\begin{array}{c}\text { Recovery } \\
\%\end{array}$ & $\begin{array}{l}\text { Purification } \\
\text { (folds) }\end{array}$ \\
\hline $\begin{array}{c}\text { *C.F.F. } \\
(\text { Volume }=200 \mathrm{ml})\end{array}$ & 129.3 & 314 & 2.4 & 100 & 1.0 \\
\hline$* *$ C.F.D. & 129.0 & 305 & 2.3 & 97.1 & 0.98 \\
\hline $\begin{array}{l}* * * \text { C.F.P. } \\
{[1: 1 \text { methanol }]}\end{array}$ & 45.61 & 298 & 6.5 & 94.9 & 2.7 \\
\hline Gel filtration (Sephadex G-100) & 7.36 & 242 & 32.9 & 77.1 & 13.7 \\
\hline $\begin{array}{l}\text { Ion-exchange chromatography } \\
\text { DEAE-Cellulose }\end{array}$ & 2.11 & 213 & 100.9 & 67.8 & 42.0 \\
\hline
\end{tabular}

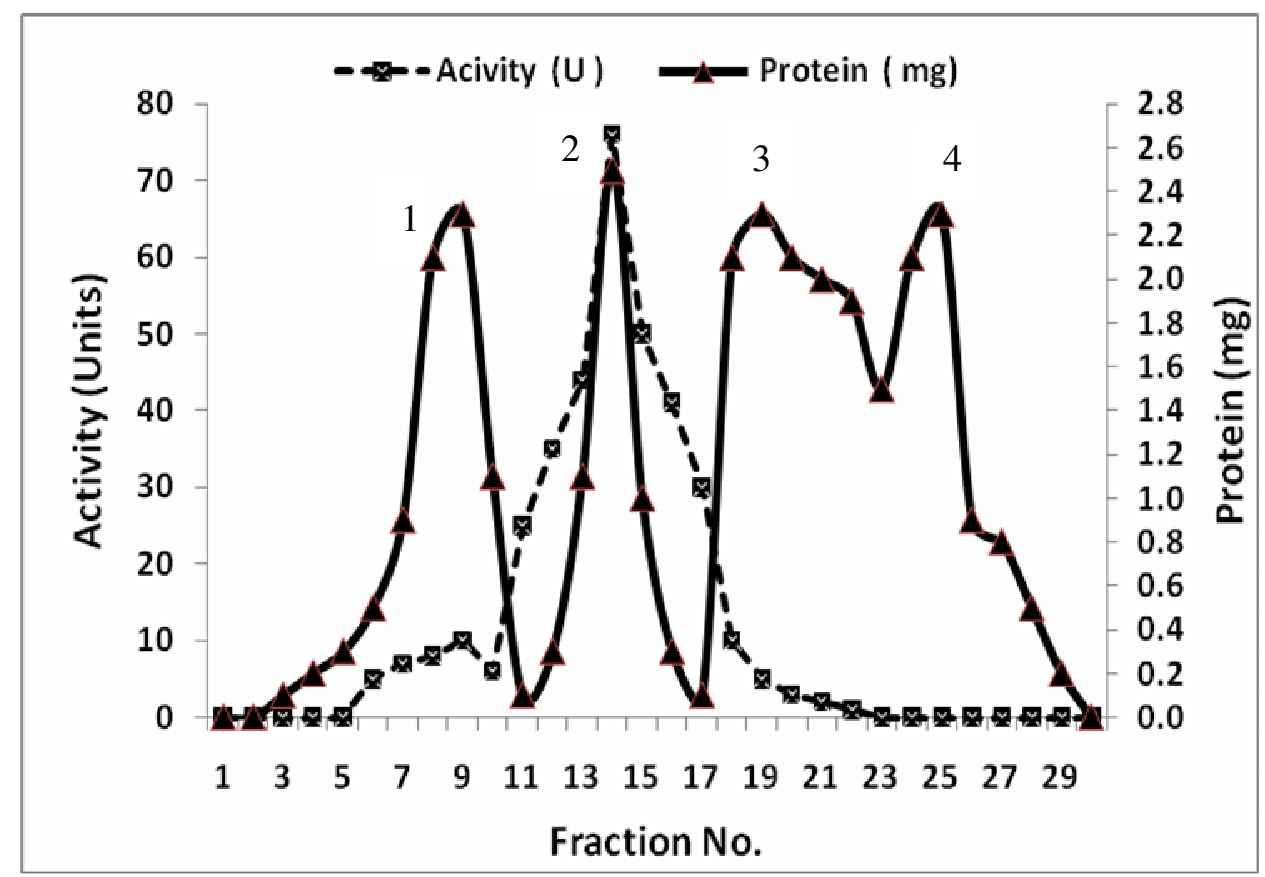

Figure 1. Purification of Inulinase I from Thielavia terrestris using gel filtration on Sephadex G-100 


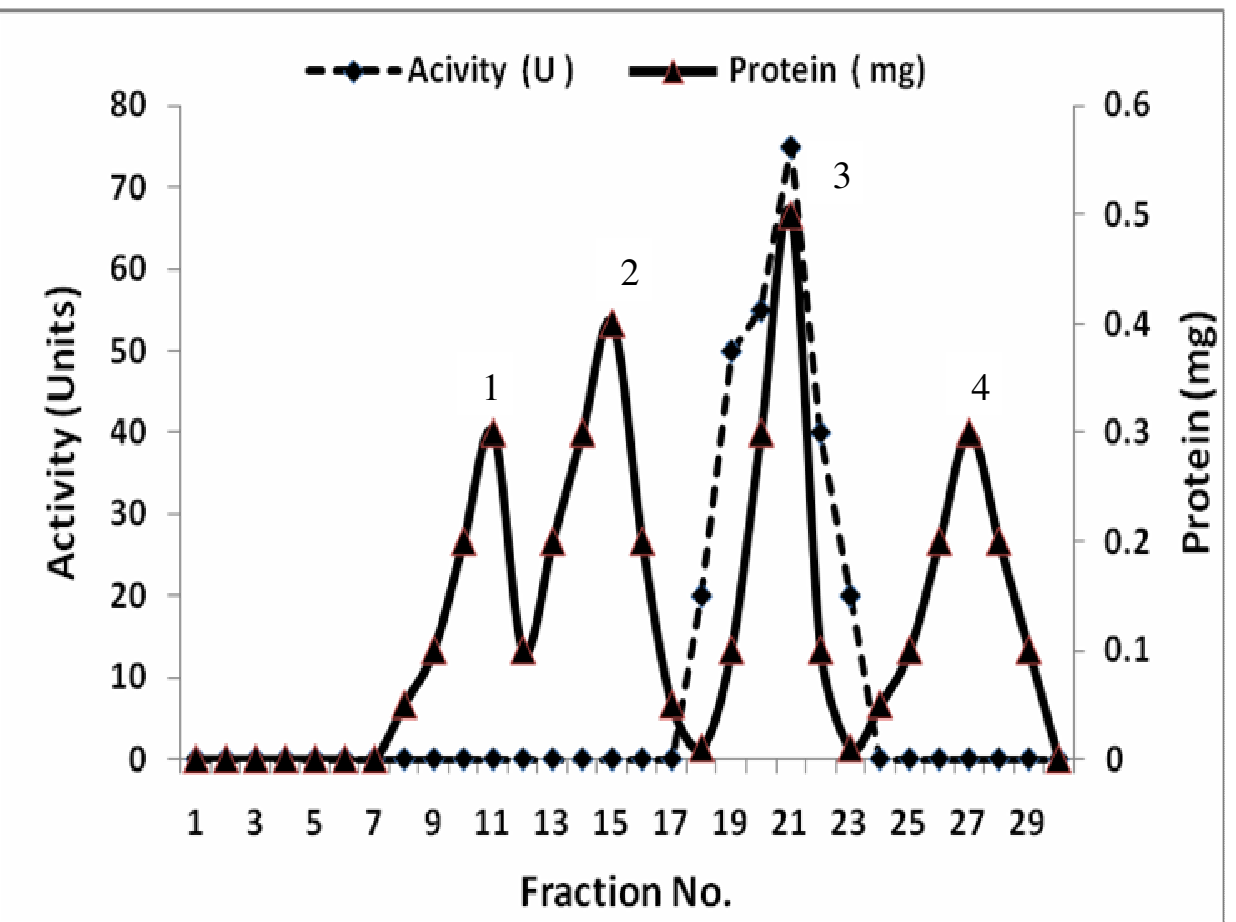

Figure 2. Purification of Inulinase I from Thielavia terrestris using ion exchange on DEAE-Cellulose.

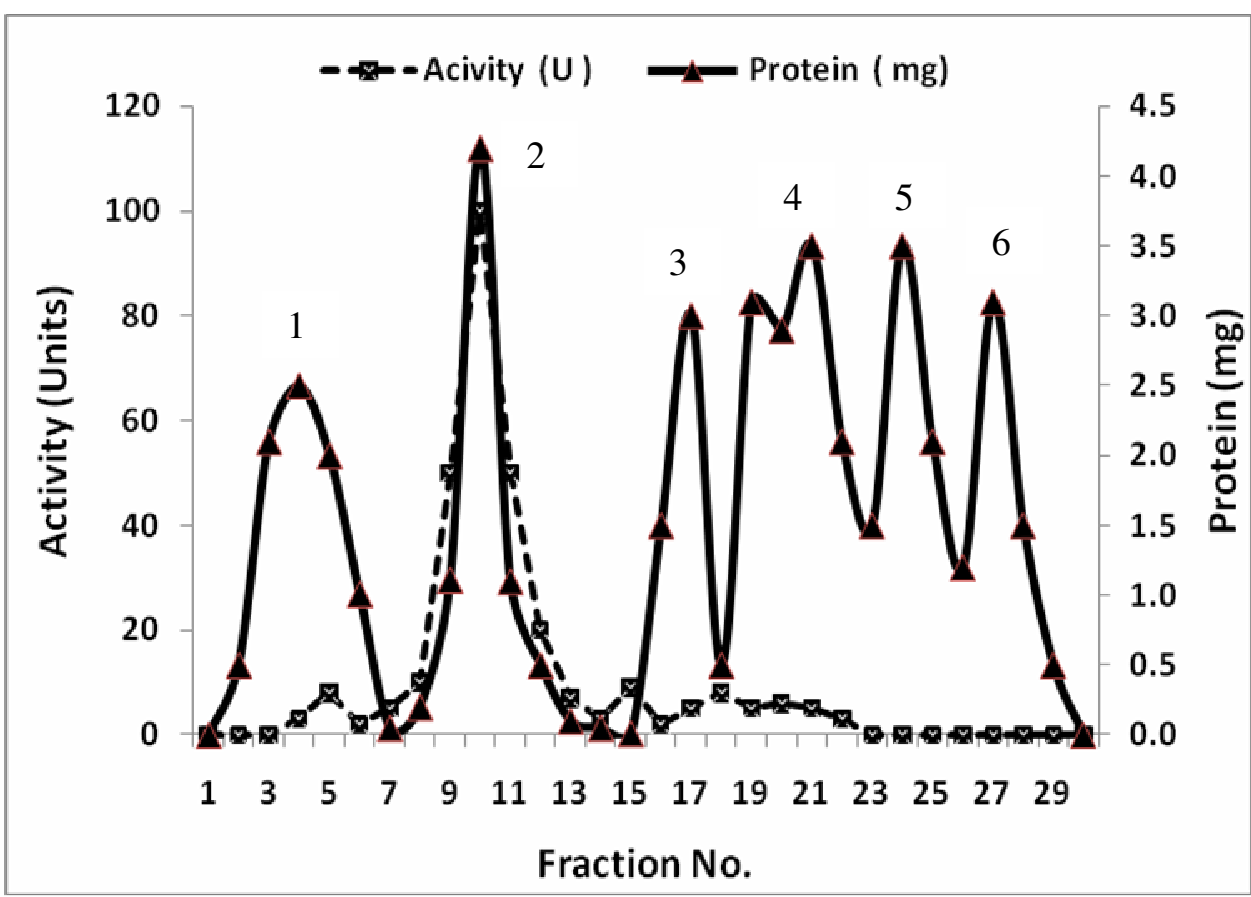

Figure 3. Purification of Inulinase II from Aspergillus foetidus using gel filtration on Sephadex G-100. 


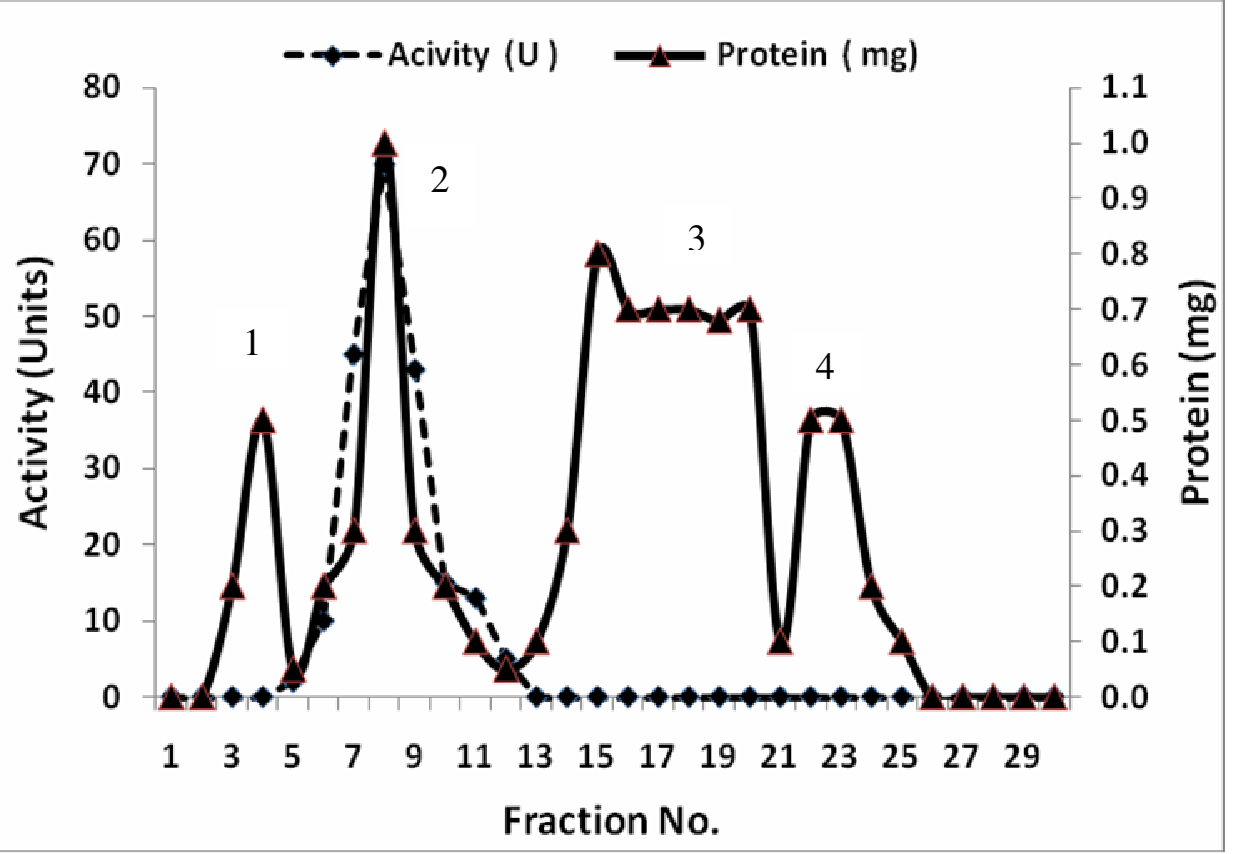

Figure 4. Purification of Inulinase II from Aspergillus foetidus using ion exchange on DEAE-Cellulose.



Figure 5. The effect of different temperature on the specific activities of inulinase I from Thielavia terrestris and inulinase II from Aspergillus foetidus. 


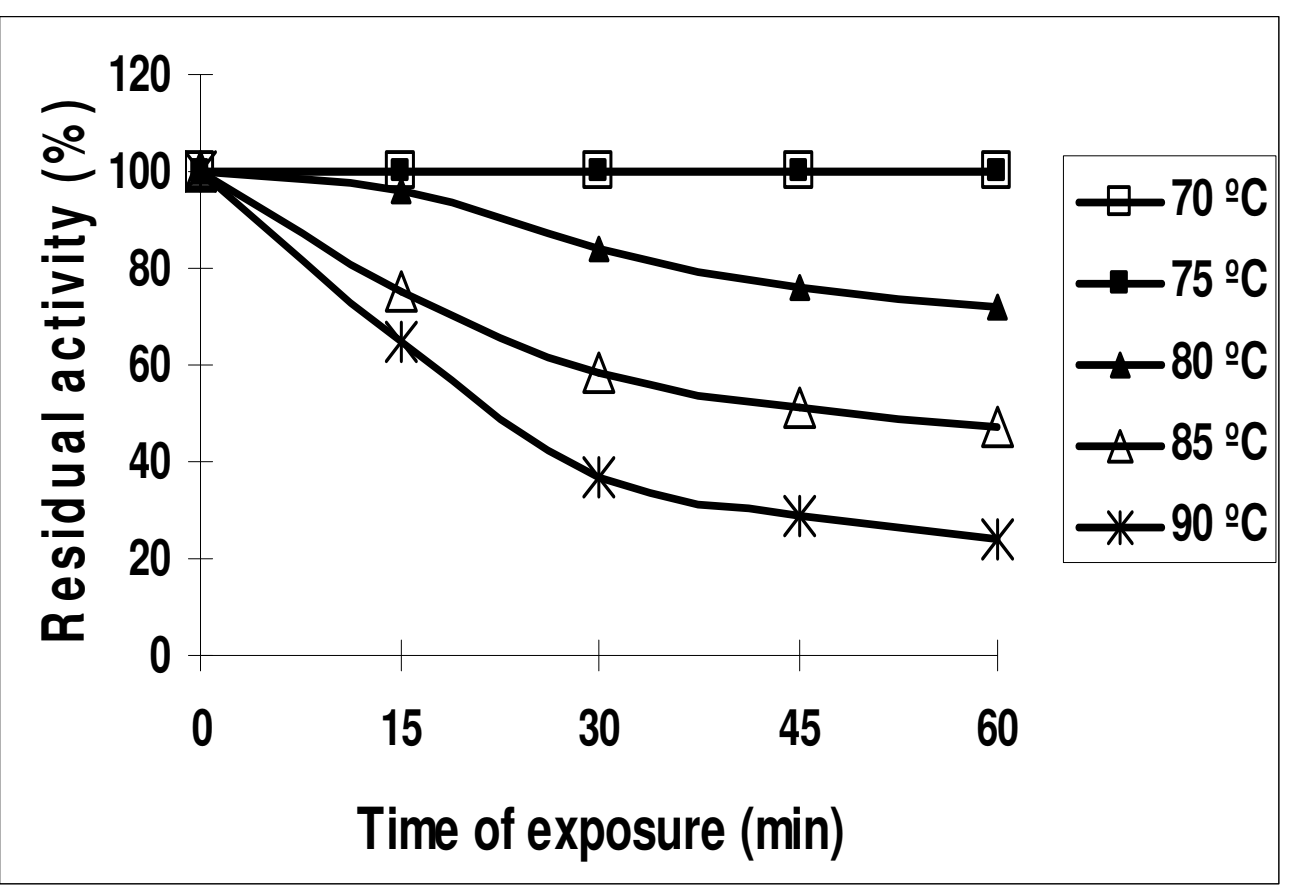

Figure 6. Thermal stability of the purified inulinase I from Thielavia terrestris

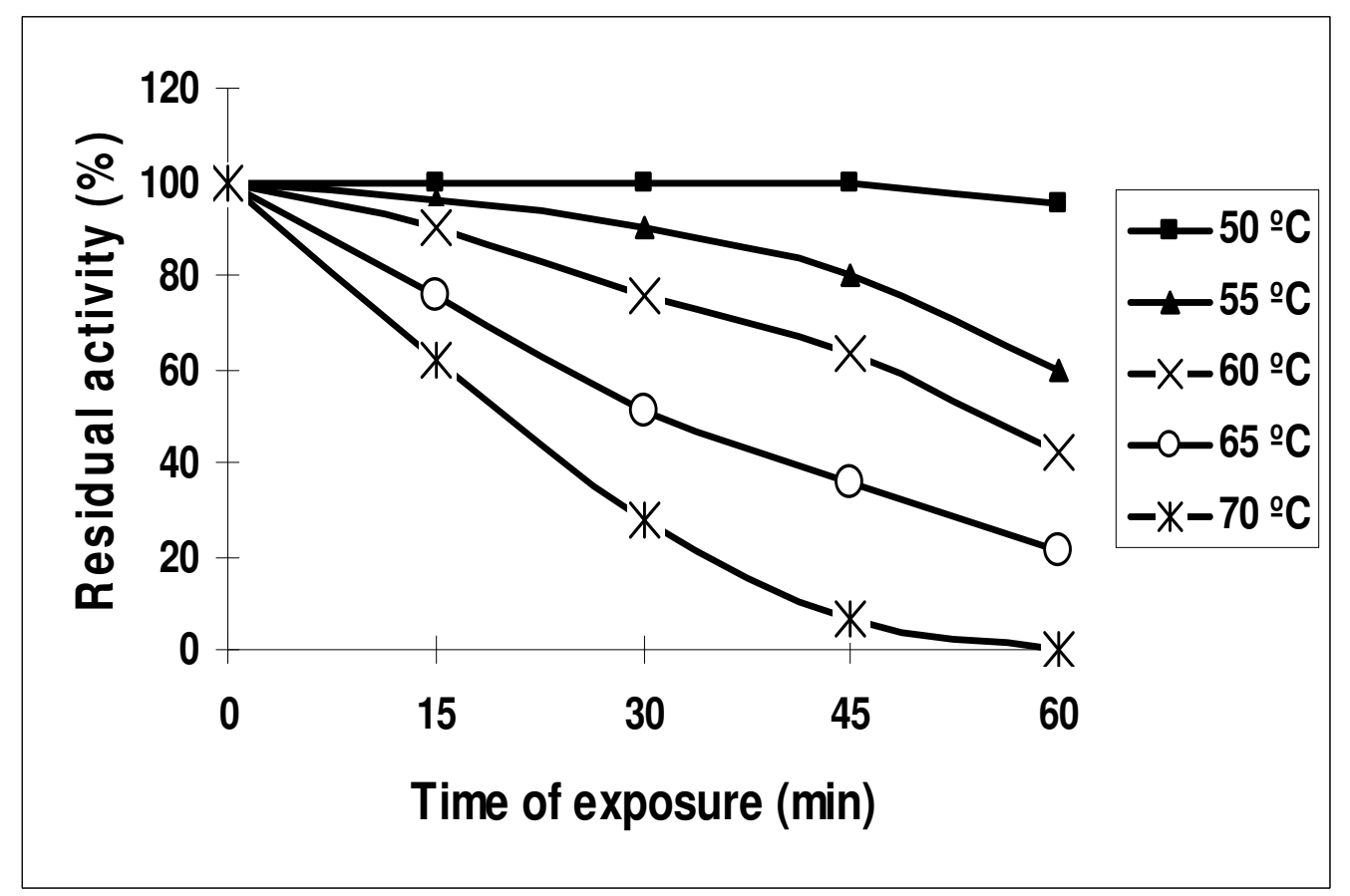

Figure 7. Thermal stability of the purified inulinase II from Aspergillus foetidus 


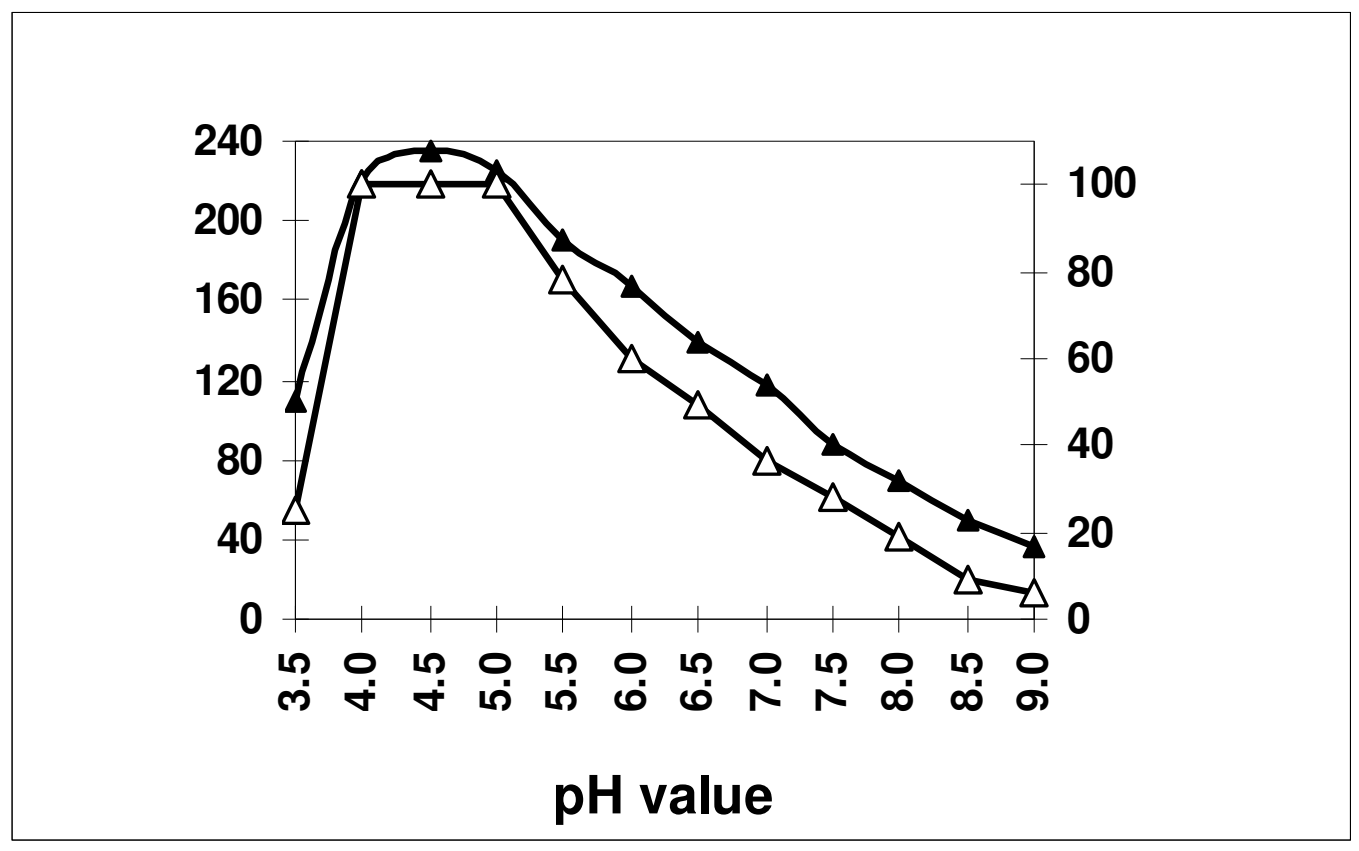

Figure 8. Effect of $\mathrm{pH}$ on the specific activity (- $\left.\boldsymbol{\Delta}_{-}\right)$and stability $\left(-\Delta_{-}\right)$of the purified inulinase I from Thielavia terrestris. The enzyme preparation was held at the indicated $\mathrm{pH}$ for $20 \mathrm{~min}$. for measuring the activity and for $1 \mathrm{hr}$. in case of stability.

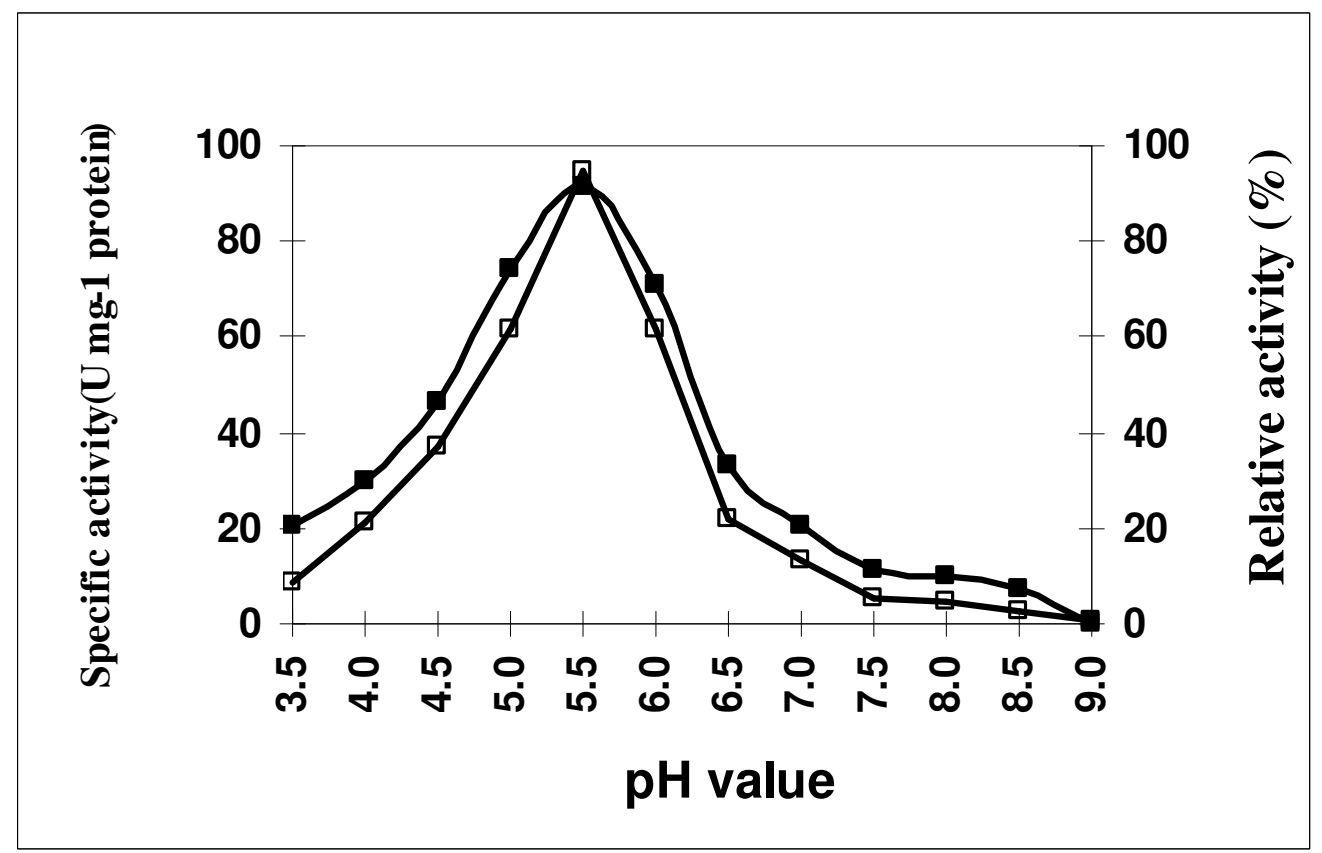

Figure 9. Effect of $\mathrm{pH}$ on the specific activity (-口-) and stability (-口-) of the purified inulinase II from Aspergillus foetidus. The enzyme preparation was held at the indicated $\mathrm{pH}$ for $20 \mathrm{~min}$. for measuring the activity and for $1 \mathrm{hr}$. in case of stability. 


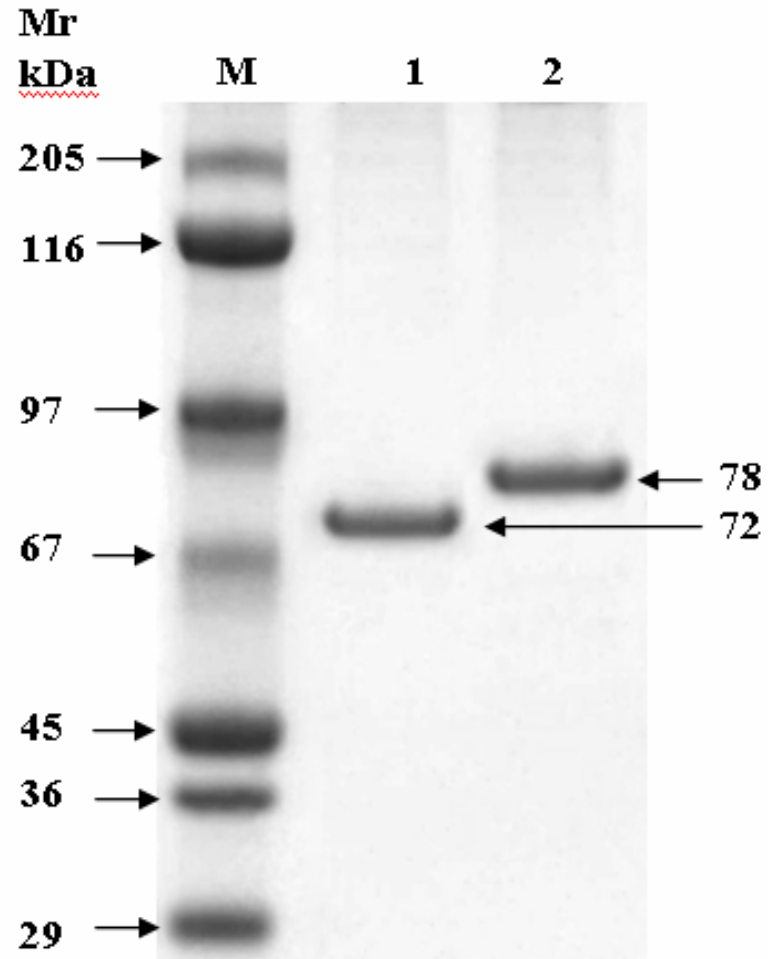

Figure 10. SDS-PAGE of the two purified Inulinase I \& II eluted from DEAE-Cellulose column (Inulinase I from Thielavia terrestris $=72 \mathrm{kDa}$; Inulinase II from Aspergillus foetidus $=78 \mathrm{kDa})$.

\section{DISCUSSION}

The thermophile Thielavia terrestris NRRL 8126 and mesophile Aspergillus foetidus NRRL 337 were selected for the present study after screening 30 fungal species (24 mesophiles, 1 thermotolerent and 5 thermophiles) for their capacity to synthesis extracellular inulinases (8.42 and 8.36 $\mathrm{U} / \mathrm{ml}$ respectively) after being grown on basal growth medium containing Chicory root extract $2 \%(\mathrm{w} / \mathrm{v})$ as a sole carbon source (Table 1). However, in a previous study, Aspergillus niveus and Penicillum purpurogenum when grown on chicory root gave the highest inulinase activity at 7.0 and $9.00 \mathrm{U} / \mathrm{ml}$ respectively (26). The selection of the aforementioned two fungi aimed at throwing some light and comparing between the production and purification of inulinase from the two different fungi. T. terrestris and A. foetidus have an ideal temperature for growth of $50^{\circ} \mathrm{C}$ and $24^{\circ} \mathrm{C}$ respectively (8).

In this work, some experiments were performed to evaluate the effect of different concentrations of Chicory root extract, different organic \& inorganic sources and different incubation periods on inulinases activity. The results were given in Tables 2, $3 \& 4$ respectively. The best concentration of chicory root extract in cultivation media for elevating the two inulinases activity was $4 \% \mathrm{w} / \mathrm{v}$ (Table 2). In this respect, other authors reported different optimum concentrations of composite plants extracts: $3 \%$ for Jerusalem artichoke $(2,12)$ and $5 \%$ for sunflower (11) as carbon sources for inulinases production. These different concentrations varied according to the type of plants $(38,39,44,45)$. Yeast extract and peptone showed superiority over inorganic nitrogen sources for the production of inulinases I \& II from $T$. terrestris and $A$. foetidus respectively (Table 3), these results were also reported two authors $(11,12)$. It appears that each fungal species has a preference for a specific nitrogen source for optimum production of inulinase (6). Inulinase I from the thermophile $T$. terrestris achieved its higher activity after 5 days of incubation, while 7 days was the ideal incubation for inulinase II productivity from A. foetidus (Table 4). This finding was in accordance with previous authors $(1,9,10,16)$ who showed that thermophiles in general, possess a more faster rate of enzyme production than mesophiles.

Concerning the purification steps, the superiority of isopropanol and methanol in obtaining protein fraction having the highest total enzyme activity confirmed that inulinase has a particular structure which makes it resist the known denaturing effect of organic solvents (Tables 5, 6). Suitability of organic solvents in this regard was previously recorded by several authors $(18,48,49)$.

Concerning the effect of temperature on the two inulinases activities (Fig 5), inulinase I was highly optimal at $75^{\circ} \mathrm{C}$, showing complete stability for one hour at the aforementioned 
degree than inulinase II which was optimal at only $50^{\circ} \mathrm{C}$. Inulinase I also showed high stability up to $85^{\circ} \mathrm{C}$ for $15 \mathrm{~min}$. (Fig 6). This result is in agreement to a certain extent with the results obtained for other inulinases from Aspergillus ficuum (9), and Aspergillus fumigatus (16). Inulinase II showed less stability (Fig. 7) when compared with inulinase I from the thermophile $T$. terrestris. Thus, the higher thermostability of inulinase I makes it a potential candidate for commercial production of fructose (46).

The optimum $\mathrm{pH}$ lies in acidic range (4.5 \& 5.5) for activity of inulinases I \& II (Fig. $8 \& 9$ ), this pH range was identical to that recorded for inulinase (4.5) from A. niger-245 (7), 5.0 from A. niger, (50), and P. janczewskii, 5.0 (32, 33). As $\mathrm{pH}$ value diverged from the optimum level, the efficient functioning of the enzyme was affected, most probably, due to the change in active site conformation which is determined, in part, by ionic and hydrogen bonding that can be affected by $\mathrm{pH}$. It is also clear that inulinase I was more stable than inulinase II where the original activity were not affected at 4.5 $-5.0 \mathrm{pH}$ for $60 \mathrm{~min}$. while inulinase II retained only $94.4 \%$ of its original activity at its optimum $\mathrm{pH}$ value (5.5).

$\mathrm{K}_{\mathrm{m}}$ value was calculated to be 2.15 and $3.45 \mathrm{mg} / \mathrm{ml}$ for inulinases I \& II respectively. $\mathrm{K}_{\mathrm{m}}$ values of inulinase of Aspergillus versicolor (19) and Penicillium janczewskii (33) were recorded at 3.8 and $4.4 \mathrm{mg} / \mathrm{ml}$ respectively. Moreover, comparatively lower $\mathrm{k}_{\mathrm{m}}$ value $(2.15 \mathrm{mg} / \mathrm{ml})$ and higher maximum initial velocity $(115 \mu \mathrm{mol} / \mathrm{min} / \mathrm{mg}$ of protein) for inulinase I demonstrate the exoinulinase's greater affinity for inulin substrate. These findings are significant for its potential industrial application (31). The lower molecular mass (Fig. 10) of the inulinase I $(72 \mathrm{kDa})$ than inulinase II $(78 \mathrm{kDa})$ often evaluate the relative affinities of this enzyme (40).

Finally, thermophiles and especially thermophilic enzymes have gained a great deal of interest both as analytical tools, and as biocatalysts for application on a large scale. Utilization of these enzymes is up to our present day, despite many efforts, often limited by the cost of the enzymes (46).
With an increasing market for the enzymes, leading to production in higher volumes, the cost is however predicted to decrease. Moreover, with a paradigm shift in industry moving from fossil fuels towards renewable resource utilization, the need of microbial catalysts is predicted to increase, and certainly there will be a continued and increased need of thermostable selective biocatalysts in the future.

\section{CONCLUSION}

Inulinases are promising candidates for use as complements in food ingredients and in the production of fermenting sugars. However, their utilization was limited due to the high cost of their production. Chicory is a very common wild plant in Egypt and so can be used as a cheap substrate for the commercial production of inulinase. The abundance of inulinases production by Thielavia terrestris and Aspergillus foetidus and the remarkable higher thermostability of inulinase I from $T$. terrestris can have a positive effect on enzyme industry.

\section{ACKNOWLEDGEMENTS}

The author wishes to express her deepest gratitude to Prof. Dr. Ahmed Fouad Afifi, Professor of Microbiology and Formerly Head of Biological Sciences Department, Faculty of Education, Ain Shams Univ. for revising the manuscript, his useful criticism and continuous encouragement.

\section{REFERENCES}

1. Baratti, J.; Ettalibi, M. (1993). Thermostable inulinases from Aspergillus ficuum: biochemical characterization and biotechnological applications. In: Fuchs A (ed), Inulin and inulin-containing crops. Elsevier, Amsterdam, pp, 211-221.

2. Barta, J. (1993). Jerusalem artichoke as a multipurpose raw material for food products of high fructose or inulin content. In: Fuchs A (ed) Inulin and inulin-containing crops. Elsevier, Amsterdam, pp. 323-339.

3. Bender, J.P,; Mazutti, M. A.; Luccio, M. D.; Treichel, H. (2008). 
Extraction of Inulinase Obtained by Solid State Fermentation of Sugarcane Bagasse by Kluyveromyces marxianus NRRL Y-7571. Appl. Biochem. Biotechnol. 149, 195-203.

4. Bradford, M.A. (1976). Rapid and sensitive method for quantitation of microgram quantities of protein utilizing the principle of protein-dye binding. Anal Biochem, 72, 248- 254.

5. Chen, H. Q.; Chen, X. M.; Li, Y.; Wang, J.; Jin, Z.Y.; Xu, X. M.; Zhao, J.W.; Chen, T. X.; Xie, Z.J. (2009). Purification and characterisation of exo- and endo-inulinase from Aspergillus ficuum JNSP5-06. Food Chemistry.115, 1206-1212.

6. Choi, W.S.; Choe, Y.K.; Kim, S.; Byun, S.M. (1984). Production of inulase using Jerusalem artichoke tuber extract. J. Korean Agri. Chem. Soc.27, 238-244.

7. Cruz, V.D.; Belote, J.G.; Belline, M.Z.; Cruz, R. (1998). Production and action pattern of inulinase from Aspergillus niger. 245: hydrolysis of inulin from several sources. Revista-de-Microbiologia, 29, 301-306.

8. DSMZ - Deutsche Sammlung von Mikroorganismen und Zellkulturen GmbH Inhoffenstraße 7B-38124 Braunschweig. Germany. Online http://www.dsmz.de/dsmz/main.php?contentleft_id=16.

9. Ettalibi, M.; Baratti, J.C. (2001). Sucrose hydrolysis by thermostable immobilized inulinases from Aspergillus ficuum. Enzyme Microb Technol. 28, 596-601.

10. Ferreira, M.S.; De Andrade, A.V.; Kennedy, J.F. (1991). Properties of a thermostable nonspecific fructofuranosidase produced by Cladosporium cladosporioides cells for hydrolysis of Jerusalem artichoke extract, Appl. Biochem. Biotechnol. 31, 1-9.

11. Fleming, S.E.; GrootWassink, J.W.D. (1979). Preparation of high fructose syrup from the tubers of the Jerusalem artichoke (Helianthus tuberosus L.), CRC Crit. Rev. Food Sci. Nutr. 12, 1-28.

12. Fontana, A.; rmann, B.; Guiraud, J.P. (1993). Production of highfructose-containing syrups from Jerusalem artichoke extracts with fructose enrichment through fermentation. In: Fuchs A (ed) Inulin and inulin-containing crops, Elsevier, Amsterdam, pp, 251-258.

13. Frank, A.; Leenheer, L.D. (2002). Inulin. In: Vandamme EJ, De Baets S, Steinbu" chel A (eds) Biopolymers, polysaccharides II: polysaccharides from eukaryotes, vol 6. Wiley-VCH, Weinheim, pp 439-479.

14. Gao, W.; Bao, Y.; Liu, Y.; Zhang, X.; Wang, J.; An, L. (2009). Characterization of Thermo-stable Endoinulinase from a New Strain Bacillus Smithii T7. Appl. Biochem. Biotechnol. 157, 498-506.

15. Gill, P.K.; Manhas, R.K.; Singh, J.; Singh, P. (2004). Purification and characterization of an exo-inulinase from Aspergillus fumigatus, Appl. Biochem. Biotechnol. 117, 19-32.

16. Gill, P.K.; Manhas, R.K.; Singh, P. (2006). Comparative analysis of thermostability of extracellular inulinase activity from Aspergillus fumigatus with commercially available (Novozyme) inulinase, Bioresour. Technol. 97, 355-358.
17. Glantz, A. S. (1992). Primer of biostatistics. (edited by McGraw Hill, Inc., U. S. A.) 2-18.

18. Hamdy, H.S. (2002). Purification and some important characters of extracellular inulinase of Alternaria alternata (Fr.) Keissler. Indian $J$ Exp Biol. 40, 1393-1398.

19. Kochhar, A.; Gupta, A.K.; Kaur, N. (1999). Purification and immobilization of inulinase from Aspergillus candidus for producing fructose, J. Sci. Food Agric. 79, 549-554.

20. Laemmli, U.K. (1970) Cleavage of structural proteins during the assembly of the head of bacteriophage T4. Nature 227, 680-685.

21. Mazutti, M. A.; Skrowonski, A.; Boni, G.; Zabot, G. L .; Silva, M. F.; Oliveira, J.V.; Luccio, M.; Filho, F. M.; Rodrigues, M. I.; Treichel, H. (2009). Partial Characterization of Inulinases Obtained by Submerged and Solid-State Fermentation Using Agroindustrial Residues as Substrates: A Comparative Study. Appl. Biochem. Biotechnol. 22732289.

22. Mazutti, M. A.; Corazza, M. L.; Maugeri, F. Rodrigues, M. I. Oliveira, J. V. Treichel, H. Corazza, F. C. (2010). Hybrid modeling of inulinase bioproduction process. J Chem Technol Biotechnol. 85, 512 - 519.

23. Miller, G.L. (1959). Use of dinitrosalicylic acid reagent for determination of reducing sugar. Anal Chem 31, 426-428.

24. Mutanda, T.; Wilhelmi, B.S.; Whiteley, C.G. (2008). Controlled Production of Fructose by an Exoinulinase from Aspergillus Ficuum. Appl. Biochem. Biotechnol. 10, 479-486.

25. Nakamura, T.; Shitara, A.; Matsuda, S.; Matsuo, T.; Suiko, M.; Ohta, K. (1997). Production, purification and properties of an endoinulinase of Penicillium sp. TN-88 that liberates inulotriose. J. Ferment. Bioeng. 84, 313-318.

26. Nandogopal, S.; Kumari, B.D.R. (2006). Enhancement of Inulinase Production from Chicory and Fenugreek Rhizosphere Soil. AmericanEurasian J. Agric. Environ. Sci. 1(3), 225-228.

27. Nguyen, Q.D.; Mattes, F.; Hoschke, A.; Szabo, J.R.; Bhat, M.K. (1999). Production, purification and identification of fructooligosaccharides produced by b-fructofuranosidase from Aspergillus niger IMI 303386, Biotechnol. Lett. 21, 183-186.

28. Ohta, K.; Norio, N.; Nakamura, T. (2002). Purification and properties of an extracellular inulinases from Rhizopus sp. Strain TN-96. J Biosci Bioeng. 94, 78-80.

29. Onodera, S.; Shiomi, N. (1988). Purification and substrate specificity of endo-type inulinases from Penicillium purpurogenum. Agric Biol Chem 52, 2569-2576.

30. Onodera, S.; Shiomi, N. (1992). Purification and subsite affini-ties of exo-inulinase from Penicillium trzebinskii. Biosci. Bio-technol. Biochem. 56, 1443-1447.

31. Palmer, T. (1991). Extraction and Purification of Enzymes. In “Understanding Enzymes" Ellis Horwood. Ltd., England, pp, 301-317. 
32. Pessoni, R. A.; Freshour, G; Figueiredo-Ribeiro, R.C.L.; Hahn, M. G.; Braga, M. R. (2002). Woronin Bodies in Penicillium janczewskii Zaleski, Braz. J. Microbiol. 33, 127-130.

33. Pessoni, R.A.; Braga, M.R.; Figueiredo-Ribeiro, R.C.L. (2007) Purification and properties of exo-inulinases from Penicillium janczewskii growing on distinct carbon sources. Mycologia. 99 (4), 493 503.

34. Peterson, E.A.; Sober, H.A. (1962). Column chromatography of protein: Substituted cellulases. In: Methods in Enzymology. Vol. 5(S. Colowich and N. Kapllan Eds.) New York. 3-27.

35. Rhee, S.K.; Song, K.B.; Kim, C.H.; Park, B.S.; Jang, E.K.; Jang, K.H. (2002). (Levan. In: Vandamme EJ, De Baets S, Steinbu“ chel A (eds) Biopolymers, polysaccharides I: polysaccharides from prokaryotes, vol 5. Wiley-VCH, Weinheim. Pp, 351-377.

36. Roberfroid, M.B.; van Loo, J.A.E.; Gibson, G.R. (1998) "The bifidogenic nature of chicory inulin and its hydrolysis products", The Journal of Nutrition, Vol. 128, 11-19.

37. Saber, W.I.A.; N.E. El-Naggar, 2009. Optimization of fermentation conditions for the biosynthesis of inulinase by the new source; Aspergillus tamarii and hydrolysis of some inulin containing agro-wastes. Biotechnology. 8: 425-433.

38. Saengthongpinit, W.; Sajjaanantakul, T. (2005). Influence of harvest time and storage temperature on characteristics of inulin from Jerusalem artichoke (Helainthus tuberosus L.) tubers. Postharvest Biol Technol. 37, 93-100.

39. Sanal, F.E.; Ertan, F.; Aktac, T. (2005). Production of Exo-inulinase from Alternaria alternata growth on Jerusalem Artichoke and some biochemical properties. Journal of Biological Sciences. 5(4), 497-505.

40. Sheng, J; Chi, Z; Gong, Li, F.J. (2008). Purification and Characterization of Extracellular Inulinase from a Marine Yeast Cryptococcus aureus G7a and Inulin Hydrolysis by the Purified Inulinase. Appl. Biochem. Biotechnol. 144:111-121.

41. Sharma, A.D.; Gill, P.K. (2006). Purification and characterization of heat-stable exo-inulinase from Streptomyces sp. J. Food Engineering. 79(4),1172-1178.
42. Sirisansaneeyakul, S.; Worawuthiyanan, N.; Vanichsriratana, W.; Srinophakun, P.; Chisti, Y. (2007). Production of fructose from inulin using mixed inulinases from Aspergillus niger and Candida guilliermondii. World J Microbiol Biotechnol. 23, 543-552.

43. Souza-Motta, C.M.; Queiroz-Cavalcanti, M.A.; Santos-Fernands, M.J.; Massa-Lima, D.M.; Nascimento, J.P.; Laranjeira, D. (2003). Identification and characterization of filamentous fungi isolated from the sunflower (Hellanthus annus L.) Rhizosphere according to their capacity to hydrolyse inulin. Braz. J. Microbiol. 34, 273-280.

44. Souza-Motta, C.M.; Queiroz-Cavalcanti, M.A.; Figueiredo-Porto, A.L.; Moreira, K.A.; Lima-Filho, J.L. (2005). Aspergillus niveus Blochwitz 4128URM: New Source for Inulinase Production. Brazilian Archives of Biology and Technology. 48, 343-350.

45. Stolzenburg, K. (2005). Jerusalem artichokes-raw material for inulin and fructose production. Zuckerindustrie 130, 193-200.

46. Turner, P.; Mamo, G.; Karlsson, E.N. (2007). Potential and utilization of thermophiles and thermostable enzymes in biorefining. Microbial cell Factories. 6, 2859-2869.

47. Vandamme, E.J.; Derycke, D.G. (1983). Microbial inulinases: Fermentation process, properties and applications, Adv. Appl. Microbiol. 29, 139-176

48. Viswanathan, P.; Kulkarni, P.R. (1995). Properties and application of inulinase obtained by fermentation of costus (Saussurea lappa) root powder with Aspergillus niger. Nahrung. 39, 288-294.

49. Vullo, D.L.; Coto, C.E.; Sineriz, F. (1991). Characteristics of an inulinase produced by Bacillus subtilis 430A, a strain isolated from the rhizosphere of Vernonia herbacea (Vell Rusby). Appl Environ Microbiol. 57, 23922394.

50. Wallis, G.L.F.; Hemming, F.; Peberdy, J.F. (1997). Secretion of two betafructofuranosidase by Aspergillus niger growing in sucrose. Arch Biochem Biophys 345(2), 214-222.

51. Xiao, R.; Tanida, M.; Takao, S. (1988). Inulinase from Chrysosporium pannorum. J. Ferment. Technol. 66, 553-558.

52. Zar, J. (1999). Biostatistical Analysis. (4th ed.) Upper Saddle River, NJ, Prentice Hall. 